\title{
THE EFFECT OF FRIVOLOUS LAWSUITS ON THE SETTLEMENT OF LITIGATION
}

\author{
AVERY KATZ \\ Department of Economics and Law School, University of Michigan, Ann \\ Arbor, MI 48109, U.S.A.
}

\section{INTRODUCTION}

It is commonly alleged that a substantial proportion of lawsuits are frivolous or "strike" suits, that is, lacking merit and filed only in the hopes of obtaining a favorable settlement. ${ }^{1}$ The handling of such suits has given rise to popular and scholarly criticisms of American civil procedure, on grounds both of efficiency and fairness. Indeed, in certain areas such as medical malpractice, antitrust, and corporation law, the asserted prevalence of frivolous suits is commonly cited as an argument for law reform. For example, recent critiques of treble damages in antitrust have emphasized the supposed encouragement such damages give to strike suits.

The fairness objection to frivolous lawsuits is that such suits can result in opportunistic persons obtaining payments to which they are not entitled, at the expense of innocent defendants who may be viewed as defrauded or under duress. The efficiency objection is that the rent-seeking occasioned by frivolous suits wastes resources both directly and indirectly. Direct costs include resources used in filing and defending such suits, as well as costs of investigation and discovery as defendants attempt to distinguish frivolous from genuine claims. Indirect costs stem from the additional trials required because the presence of frivolous plaintiffs in the population of litigants interferes with the settlement of genuine claims.

This article develops a model of litigation and settlement in the presence of frivolous lawsuits, which I define as suits that have a sufficiently low chance of prevailing at trial that they would not be brought but for the prospect of settlement. The analysis does not address suits in which the prospect of judicial error or jury confusion at trial permits a plaintiff to obtain a settlement that is undeserved according to some external normative standard. Instead, I take a strictly positive view of the law and treat all suits expected to prevail at trial as genuine. Neither do I address suits that turn out ex post to have little basis in law, but that ex ante seemed plausible. There are undoubtedly many such cases brought, but it is

I am grateful to Richard Caves, Sharon Feldman, Louis Kaplow, Joseph P. Kalt, Gregory Mankiw, Stephen Salant, Steven Shavell, Michelle White, and an anonymous referee for helpful comments and discussions. This paper is based on chapter III of my Ph.D. dissertation (1986).

'See, e.g., the discussion in Rowe (1984), at p. 151.

(C) 1990 Butterworth Publishers 
difficult to call them frivolous, since the plaintiffs believe with some reason that the law may entitle them to a recovery. ${ }^{2}$

There has developed a substantial literature on litigation and settlement under imperfect information. Most contributors to this literature, however, have assumed the plaintiff's threat to go to trial to be credible, thus ruling out the possibility of frivolous lawsuits. In order to explain how frivolous suits can persist, it is necessary to explain why defendants might be willing to offer positive amounts in settlement to a frivolous suitor. The first formal analysis of the problem was by David Rosenberg and Steven Shavell (1985), who showed that even when the defendant fully realizes that a claim is frivolous, the plaintiff may still obtain a positive settlement. This is because the defendant is willing to pay a settlement up to the amount of his defense costs in order to avoid having to respond to the plaintiff's complaint. This result, however, depends upon two particular assumptions of the Rosenberg-Shavell framework. First, they assume that the plaintiff, and not the defendant, can commit to making a take-it-or-leave-it settlement offer. ${ }^{3}$ Second, and more importantly, they assume that once suit has been brought, the defendant must spend a substantial amount in defense before the plaintiff has to spend any substantial amount offensively.

In reality, however, a defendant who knows a suit to be frivolous can merely respond with a blanket denial of the plaintiff's allegations. This will suffice to avoid a default and will shift the burden of the next expenditure back to the plaintiff. Since the plaintiff's ultimate threat to go to trial is not credible, the defendant may be able to ignore it. The Rosenberg-Shavell model, while helping to explain those nuisance suits that settle for small amounts, cannot explain either why defendants might react to frivolous suits with more than a minimal response, or why frivolous suits might settle for amounts greater than the cost of a minimal response.

The main reason that frivolous suits are not always met with a blanket denial and refusal to negotiate, of course, is that the defendant rarely knows the merits of the claim with certainty. Since refusing to take a valid claim seriously can be quite costly, a frivolous plaintiff may be able to take advantage of the defendant's uncertainty regarding the claim's validity to extract a substantial settlement.

This article presents a model that explains strike suits as a result of defendant uncertainty regarding the merit of plaintiffs' claims. The model views the settlement process as an asymmetric information game. Specifically, I assume that

${ }^{2}$ Ivan P'ng (1983) considers this possibility in a model in which an informed defendant chooses whether to offer an exogenous settlement to an uninformed plaintiff. The defendant in P'ng's model may be induced to offer a positive amount to a plaintiff who would not go to trial. It is difficult to describe P'ng's plaintiff as a strike suitor, however, since he does not know when he brings suit whether his case is a winner. Furthermore, P'ng's equilibrium is not subgame perfect; in it the defendant responds to an incredible threat by the plaintiff.

${ }^{3}$ If the defendant can commit to a take-it-or-leave-it offer following suit, the defendant will make and a frivolous plaintiff will accept any offer infinitesimally greater than zero. Since a frivolous plaintiff can foresee he will be unable to resist such an offer, he will never sue if the cost of filing suit is strictly positive. Since in reality the potential strike suitor is often a one-shot litigant while the potential defendant is often a well-established person or business with incentives to establish a reputation, it is unclear why the plaintiff and not the defendant can commit to making a take-it-or-leave-it offer. Cooter and Ulen (1988, p. 486) show that the Rosenberg-Shavell argument can be extended to a situation in which the negotiation is expected to lead to the Nash cooperative bargaining solution, provided that trial costs are asymmetrical. The Nash solution, however, is well defined only in the setting of complete information. 
there are two possible types of plaintiffs: frivolous and genuine. Each plaintiff knows whether his claim is frivolous or genuine, but the defendant must base the decision whether to offer settlement on his estimate of the probability that the suit is genuine, as updated by any inferences he can draw from the plaintiff's decision to bring suit. When the opportunity to bring a frivolous lawsuit is competitive, in a sense defined below, the equilibrium number of frivolous claims is strictly proportional to the number of genuine claims. And, among the properties of the resulting equilibrium is that frivolous suits completely dissipate the surplus from settlement bargaining.

One component of this argument has also been put forward by Lucian Bebchuk (1988), in an article that appeared after the original version of this paper was written. Bebchuk investigates the circumstances in which an imperfectly informed defendant would be willing to tolerate the risk of settling with a frivolous plaintiff in order to obtain the benefit of avoiding going to trial against a genuine plaintiff. He finds, not surprisingly, that an increase in the defendant's probability estimate that the plaintiff's claim is valid makes it more likely that the defendant will offer a positive amount in settlement, and also increases the amount of the defendant's offer if it is forthcoming. More interestingly, Bebchuk finds that an increase in the defendant's trial costs will increase both the likelihood of a positive settlement offer and the amount of an offer if it is forthcoming. This is because higher trial costs raise the defendant's benefit from settling with valid claimants and makes him more willing to tolerate the cost of settling with strike suitors.

Bebchuk's analysis, however, is incomplete in that he examines only the decision problem of one party to an interactive situation-the defendant's incentives to offer settlement before trial. He ignores the issue of the frivolous plaintiff's incentive to bring suit in the first place, assuming at the outset an exogenously fixed number of frivolous plaintiffs. This assumption precludes consideration of two important features of frivolous lawsuits. First, it ignores the fact that the defendant can draw inferences about the plaintiff's private information from the fact that the plaintiff is willing to bear the cost of filing suit.

Second, and more importantly, in equilibrium the plaintiff's decision to bring suit both depends upon and influences the defendant's settlement strategy. For example, if there is no cost to bringing suit (as Bebchuk assumes), an unlimited number of frivolous plaintiffs would bring suit if they anticipated a positive settlement. But this would drive the proportion of valid claims to zero, eliminating the defendant's incentive to settle. More generally, if filing suit is costly, the proportion of frivolous suits should adjust until the returns from suit are driven to the competitive level. It should be apparent that solving one party's decision problem in this context is not the same thing as solving for the equilibrium outcome.

Accordingly, when the plaintiff's decision to bring suit is appropriately recognized as endogenous, the nature of the outcome changes substantially. This result should be familiar to those acquainted with the economic literature on rentseeking, which holds that the equilibrium amount and outcome of redistributive activity depends critically on whether access to that activity is competitive. ${ }^{4}$ It is the possibility that frivolous plaintiffs will compete to bring their lawsuits that makes the potential cost of the phenomenon so high. Bebchuk's exogeneity assumption, in contrast, leads him to focus on what $I$ show below to be a special case (technically, a corner solution).

The organization of the paper proceeds as follows. Section 2 presents the basic model of frivolous lawsuits, solves for its equilibrium, and derives some results

${ }^{4}$ The classic exposition of this idea is found in Posner (1975); see also Tullock (1967). 
in comparative statics. Section 3 discusses the model's implications for a number of policy proposals for civil court procedure that have been proposed to alleviate the frivolous suit problem. Section 4 presents a variation on the basic model in which there is a continuum of plaintiff types and shows that the flavor and several results from the two-type model carry over. Section 5 summarizes the analysis and suggests some possible extensions. ${ }^{5}$

\section{THE MODEL AND ITS EQUILIBRIUM}

\section{Assumptions}

Consider a situation in which a plaintiff can plausibly claim an entitlement to legal compensation. The potential plaintiff knows with certainty whether or not he is actually injured, but the defendant knows only the probability of injury conditional on the initial event. To illustrate, consider a customer at a retail store who slips and falls on a floor that the store negligently failed to keep dry. The customer knows whether he has been hurt, but the store only knows that such falls result in injury some proportion of the time. A second example is a products liability case in which injury is undisputed, but the plaintiff is not entitled to damages if he was contributorily negligent in using the product. While the plaintiff knows whether he was negligent, the defendant cannot know in advance of trial.

The litigation process of the model occurs in four stages. First, a random event determines whether a potential plaintiff is injured. Second, the plaintiff chooses whether to sue; this depends on both the expected settlement to follow and the plaintiff's expected gains from trial should there be no settlement. Third, the dcfendant chooses a single take-it-or-leave-it settlement offer. Fourth, the plaintiff chooses whether to accept the offer, and if the offer is nonpositive, whether to drop the case or to proceed to trial. At trial the plaintiff's information is revealed, and judgment is awarded if and only if the plaintiff is actually injured. The structure of the settlement game is shown in Figure 1. Dotted lines indicate imperfect information; they connect two nodes of the game between which the defendant cannot distinguish.

\footnotetext{
${ }^{5}$ Several other articles shed light on various features of suits by plaintiffs who might not go to trial. Ordover and Rubenstein (1986) analyze a bargaining game that can be reinterpreted as a model of strike suits. They assume that the only way the suit can end is for one of the parties to give up, however, and are primarily interested in explaining the duration of a variablc bargaining period. Salant (1984) develops a litigation model in which an informed plaintiff has already filed suit at the outset and is about to make an offer to an uninformed defendant. Although Salant does not explicitly consider the issue of strike suits, his approach is sufficiently general that a reinterpretation of his notation could yield some insights about the issue. He is concerned primarily, however, with the information transmitted by the amount of the settlement offer. Also recently, a paper by Nalebuff (1987) explores a model of settlement bargaining in which it is the plaintiff rather than the defendant who is uninformed regarding the extent of injury. Because rejection of a small settlement demand can make the plaintiff's threat to litigate incredible, plaintiffs are led in Nalebuff's model to exaggerate their demands in order to limit the bad news they learn from a rejection. He interprets such exaggerated threats as nuisance suits. While the model is undoubtedly interesting and useful, one may question whether it captures the features of strike suits that have received recent public attention, particularly in that the plaintiff does not know whether the suit is frivolous when he makes his demand. A more realistic and complicated model, which combines features of Nalebuff's model with the one developed here, will be necessary in order to explore the aspects of bilaterally asymmetric information that characterize actual disputes.
} 


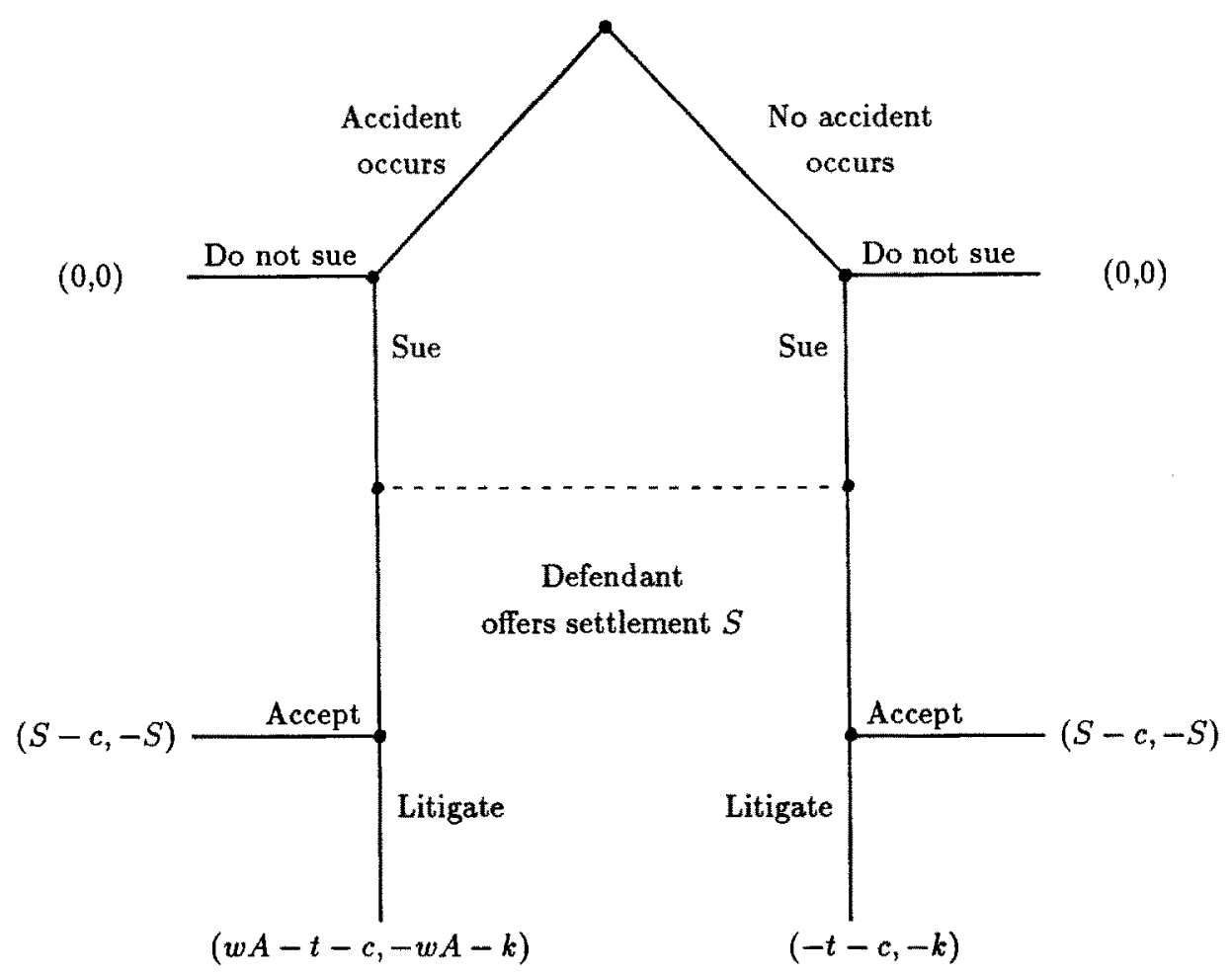

FIGURE 1. Structure of basic model

One might object that courts cannot always reliably tell whether the plaintiff's claim is valid. Recall, however, that I interpret validity in positivistic terms, so that the validity of the plaintiff's claim depends solely on the court's expected reaction to his information. All I assume is that plaintiffs can accurately foresee on average how courts will react to their information.

This framework involves a number of important assumptions. First, the assumption of a single offer is a restrictive one. I abstract from this issue since my main goal is not to provide a general solution to the bargaining problem but to focus on how bargaining over just claims can induce frivolous claims to arise. Whatever the defendant's settlement strategy, he faces a tradeoff between paying frivolous claims and risking trial against genuine claims.

Second, the assumption that the defendant makes the offer simplifies the analysis considerably, in that information regarding the plaintiff's type is conveyed only by the fact of suit and not by the amount of the offer. Which version of the model is a better description of reality may vary according to the legal context, and may depend upon the type of claim and area of substantive law.

Third, I assume that the defendant possesses no private information regarding the merits of the case. If the defendant's conduct is a major issue in the lawsuit, as in an antitrust case with allegations of conspiracy or in a suit centered on the defendant's alleged negligence, a more complicated model than this one will be needed. In such cases, however, it is more difficult to characterize the plaintiff's claim as frivolous; the problem may instead be one of a frivolous defense. 
Fourth, I abstract from the fact that in an actual lawsuit the defendant may wish to spend resources to investigate the claim's validity, for example by paying for a medical examination or by engaging in civil discovery. A strike suitor's decision will be affected by the prospect of such discovery, so that easily disprovable claims might be cheaply deterred. Since complete information is likely to be prohibitively costly, one can interpret the defendant's probability estimate as that remaining after optimal investigation. I also assume that an injured plaintiff cannot credibly communicate the validity of his claim to the defendant before trial.

With these preliminaries aside, suppose that some event occurs that with some probability, or among some proportion of a population, creates a legally valid claim. A potential plaintiff is accordingly of one of two types-injured or frivolous, with the original probability of injury denoted as $p_{0} \in[0,1]$. The extent of injury is denoted as $A$, and the likelihood of a finding of liability given that there is injury is denoted as $w \in[0,1]$; the expected award at trial for an injured plaintiff equals $w A .^{6}$

The cost of trial is denoted as $t$ for the plaintiff and as $k$ for the defendant. In addition, a plaintiff must spend $c$ to bring the lawsuit initially; this amount includes the cost of preparing and filing a complaint and making the fact of the lawsuit known to the defendant. Once suit has been brought, this initial cost is sunk and does not affect the decision to proceed to trial. The net expected gain from trial for an injured plaintiff, once suit has been brought, then equals $w A-t$; the expected cost for the defendant if an injured plaintiff goes to trial is $w A+k .^{7}$

Given this framework, I solve for the unique sequential equilibrium to this game. Each plaintiff type chooses a strategy that maximizes his return from suit given the strategies of the defendant and the other plaintiff type. The defendant chooses a strategy that minimizes his payout given the plaintiffs' strategies and given his own best estimate of the plaintiff's type. The defendant's probability estimate is formed by updating his original beliefs according to Bayes' rule. Randomized strategies are admissible and indeed are necessary for the existence of equilibrium.

\section{Solution of the model}

The requirement of sequential equilibrium implies that the game is solved by reasoning backwards from its last stage, where the plaintiff must choose between accepting the defendant's offer $S$ and going to trial. A frivolous plaintiff could obtain $S$ by accepting the offer, could obtain $-t$ by rejecting the offer, and could obtain zero by dropping the lawsuit. He would therefore accept any positive settlement offer, and would drop the lawsuit if faced with a zero or negative settlement offer. An injured plaintiff, by the same token, could obtain $S$ by accepting the offer, could obtain $w A-t$ by rejecting the offer, and could obtain zero by dropping the lawsuit. He would therefore accept a settlement if and only if it were at least as great as his expected gain from trial, $w A-t{ }^{8}$ Note that the

${ }^{6} \mathrm{I}$ allow for the possibility that a genuine plaintiff is not assured of recovery at trial. The reader may alternatively wish to interpret $w A$ as the expected value of the judgment, recognizing that potential plaintiffs can differ with respect to the extent as well as the probability of recovery.

${ }^{7}$ The defendant may also have costs prior to trial. Such costs are sunk by the time of settlement and hence do not affect the optimal settlement strategy, so I ignore them. In a model analyzing frivolous defenses as well as frivolous claims, such costs might become an important factor.

${ }^{8} \mathbf{I}$ assume without loss of generality that a plaintiff will always accept a settlement offer when indifferent. 
initial filing cost has no effect on the decision to accept settlement, since once suit is brought it is sunk.

It should be apparent that the defendant will never make a settlement offer in an amount other than the reservation prices of the two types, 0 and $w A-t$. Any offer above $w A-t$ will be accepted by both types of plaintiffs, and given this there is no reason for the defendant to make such an offer any larger than necessary. Similarly, any offer strictly between zero and $w A-t$ will be rejected by the genuinely injured plaintiffs and accepted by the frivolous plaintiffs, and as long as the genuine plaintiffs do not accept there is no reason to offer the frivolous ones anything at all.

Whether the defendant prefers to offer nothing or $w A-t$ depends upon his estimate of the probability that the plaintiff has a valid claim, conditional on suit having been brought. Denote this conditional probability as $p_{1}$; its value depends both on the prior probability $p_{0}$, and on the probabilities that the two types of plaintiffs bring suit. A genuinely injured plaintiff will always sue, because his net payoff from doing so is at least $w A-t-c$; which I have assumed is strictly positive. ${ }^{9}$ Denote as $q$ the probability that an uninjured plaintiff chooses to bring suit. According to Bayes' rule, the posterior probability $p_{1}$ is defined by the formula:

$$
p_{1}=\frac{p_{0}}{p_{0}+\left(1-p_{0}\right) q}
$$

The value of $p_{1}$ ranges from 1 to $p_{0}$ as $q$ ranges from 0 to 1 .

The defendant has the choice of paying a settlement of $w A-t$ to all plaintiffs, or offering no settlement and going to trial against only those plaintiffs who are genuinely injured. Since going to trial costs the defendant $w A+k$, he strictly prefers to settle the case if $w A-t<p_{1}(w A+k)$, or equivalently, if the posterior probability that the claim is valid exceeds a threshold level:

$$
p_{1}^{*}=\frac{w A-t}{w A+k}
$$

If the posterior probability of injury is less than the threshold $p_{1}^{*}$, the defendant strictly prefers to go to trial. And if $p_{1}=p_{1}^{*}$, the defendant is indifferent between settlement and trial.

The defendant's optimal strategy, therefore, can be described by a single variable $\sigma$, which denotes the probability that he offers the higher settlement. If $p_{1}<p_{1}^{*}$, then $\sigma=0$. If $p_{1}>p_{1}^{*}$, then $\sigma=1$. And if $p_{1}=p_{1}^{*}$, the defendant is indifferent between settlement and trial and is willing to choose $\sigma$ at any value between zero and one. ${ }^{10}$

9This assumption is essential to the formulation of the problem. If $w A-t<c$, then in equilibrium neither frivolous nor injured plaintiffs bring suit.

${ }^{10}$ The analysis would be similar if frivolous plaintiffs could expect some small return $v A$ from trial. So long as their expected return were less than their trial costs $t$, they would still drop out before trial, and the defendant's incentives would be unchanged. A slightly more complicated situation would arise if frivolous plaintiffs could expect a return from trial that exceeded trial cost $t$, but was less than the combined trial and filing costs $t+c$. In this case frivolous plaintiffs would not bring suit if they expected no settlement to be offered, but if they ever did bring suit their filing cost would be sunk and they would then be willing to go to trial. The defendant would then have to choose between settling for $w A-t$ with all plaintiffs, and settling for $v A-t$ with the frivolous plaintiffs and going to trial against the rest. The analysis of this variation follows along precisely the same lines as the text, and results in a similar equilibrium. 
Note also that associated with the threshold value of $p_{1}$ is a threshold value of $q$, equal to:

$$
q^{*}=\frac{p_{0}\left(1-p_{1}^{*}\right)}{\left(1-p_{0}\right) p_{1}^{*}}=\frac{p_{0}(t+k)}{\left(1-p_{0}\right)(w A-t)}
$$

If uninjured plaintiffs bring suit with probability greater than $q^{*}$, then the posterior probability of injury will be less than $p_{1}^{*}$, and the defendant will prefer to go to trial.

Now consider a frivolous plaintiff's decision regarding the probability of suit, $q$. (Given the original probability of injury $p_{0}$, it is equivalent to view him as choosing the value of $p_{1}$. I adopt this convention in the notation, since it makes the argument somewhat clearer.) His net return from suit equals $\sigma(w A-t)-c$, since he must spend $c$ to file and has probability $\sigma$ of getting a settlement $w A-t$. Accordingly, he will prefer to sue if and only if the probability $\sigma$ exceeds the threshold level:

$$
\sigma^{*}=\frac{c}{w A-t}
$$

in which case he will choose $q=1$ (or equivalently, $p_{1}=p_{0}$ ). If the defendant offers settlement with probability less than $\sigma^{*}$, an uninjured plaintiff will want to choose $q=0$ (or equivalently, $p_{1}=1$ ). And, if the settlement probability $\sigma$ exactly equals $\sigma^{*}$, uninjured plaintiffs will be indifferent regarding suit and willing to choose any value of $q \in[0,1]$, and any value of $p_{1} \in\left[p_{0}, 1\right]$.

A unique and stable equilibrium is defined by the two simultaneously determined variables, $p_{1}$ and $\sigma$. The equilibrium, however, can be of two types, depending upon whether the prior probability of injury, $p_{0}$, is greater or less than the threshold posterior probability $p_{1}^{*}$.

PROPOSITION 1. If the prior probability of injury is above a threshold level, the unique equilibrium involves all potential plaintiffs bringing suit, whether injured or not, and all suits resulting in settlement at the injured plaintiff's reservation price.

PROOF: If $p_{0}>p_{1}^{*}$, then it necessarily follows that $p_{1}>p_{1}^{*}$. Then the defendant must choose $\sigma=1$ in equilibrium. But then an uninjured plaintiff's return from suit is $w A-t-c>0$, so he chooses $q=1$ and $p_{1}=p_{0} *$ in equilibrium. $\|$

In this first type of equilibrium, the prior probability of injury is so high that the defendant wants to settle with all the strike suitors in order to avoid going to trial against the injured plaintiffs. This occurs because only a limited number of persons are eligible to bring suit, so there are not enough potential claimants to drive the profits from bringing a strike suit to the competitive level. Since potential strike suitors are scarce, they earn a rent in cquilibrium. Accordingly, I refer to this outcome as a "restricted entry" or noncompetitive equilibrium.

This is the outcome that Bebchuk identifies. It is a corner solution in the following sense: all possible frivolous plaintiffs bring suit. More would sue if they were eligible to do so, but their number is bounded. The limit on potential suitors makes the probability that the claim is valid effectively exogenous. ${ }^{11}$

${ }^{11}$ In Bebchuk's model, the degree of injury varies over a continuum, so that some injured plaintiffs reject the offer and go to trial in equilibrium. For a more complete analysis of the variable-injury model, see section 4 below. 
Table 1. Simulation of threshold value $p_{i}^{*}$

\begin{tabular}{lccc}
\hline & \multicolumn{3}{c}{ Ratio of total costs to stakes $\frac{t+k}{A}$} \\
\cline { 2 - 4 } Probability of & $\frac{t+k}{A}=0.25$ & $\frac{t+k}{A}=0.33$ & $\frac{t+k}{A}=0.50$ \\
\hline liability $w$ & 0.33 & 0.20 & 0.00 \\
$w=0.25$ & 0.60 & 0.50 & 0.33 \\
$w=0.50$ & 0.71 & 0.64 & 0.50 \\
$w=0.75$ & 0.78 & 0.71 & 0.60 \\
$w=1.00$ & & & \\
\hline
\end{tabular}

Source: Equation 5 in text.

To get a sense of the importance of this type of equilibrium, it is helpful to calculate some benchmark estimates of the threshold $p_{1}^{*}$. The University of Wisconsin Civil Litigation Research Project provides the best available data on litigation expenditure; they find that total trial costs in a typical lawsuit range from one-fourth to one-half of the potential stakes. ${ }^{12}$ If one assumes that the plaintiff's and defendant's trial costs are approximately equal, then:

$$
p_{1}^{*}=\frac{w A-t}{w A+k}=\frac{2 w-\frac{t+k}{A}}{2 w+\frac{t+k}{A}}
$$

Table 1 shows the threshold value of $p_{1}$ for various parameter values. For example, when an injured plaintiff is certain to win $(w=1)$ and where total costs are one-third the potential stakes $\left(\frac{t+k}{A}=0.33\right)$, then $p_{1}^{*}=0.71$. Note that the threshold rises with the probability of liability $w$ and is inversely related to the stakes-cost ratio. But for some plausible parameter values, the prior probability of injury must be substantially above $50 \%$ to support a restricted entry equilibrium.

The value of the prior probability $p_{0}$ will depend upon the specificity and exclusiveness of the initial event, as well as upon any additional information the defendant can obtain through investigation. If the defendant is unable to identify the occurrence of the initial event or the class of persons who may have participated in it, the value of $p_{0}$ will be small. To illustrate, if in the slip-and-fall case mentioned above, the set of potential plaintiffs is limited to those who actually are observed to fall, then $p_{0}$ will be fairly high. But if a customer can plausibly claim to have fallen without the store's knowledge at some time in the recent past, the set of potential plaintiffs may include all customers who have used the store; $p_{0}$ would then represent the prior probability of the compound event that a fall occurred and that it resulted in injury. The more difficulty the defendant has in defining the initial event, then, the less likely is a restricted entry equilibrium.

I will spend relatively little time discussing the restricted entry case or its comparative statics, as Bebchuk's analysis treats it thoroughly. It is worth observing, however, which factors determine whether this kind of equilibrium obtains.

${ }^{12}$ See Trubek et al. (1983). 
PROPOSITION 2. A restricted entry equilibrium is more likely to obtain, other things being equal, when

(a) the prior probability of injury is higher;

(b) the defendant's trial costs are higher;

(c) the plaintiff's trial costs are higher;

(d) the expected stakes are lower.

PROOF: By differentiation of Equation 2 with respect to $p_{0}, k, t$ and $w A$. $\|$

It is worth observing that the likelihood of a restricted entry equilibrium is unaffected by the level of filing costs, $c$. This is because the threshold probability of injury required for such an equilibrium depends only on the defendant's relative costs of trial and settlement. The defendant obviously cares about the expected stakes and about his own trial costs. He also cares about the plaintiff's trial costs since they affect the reservation price at which an injured plaintiff will settle. Since filing costs are sunk at the time of trial, however, they do not affect the plaintiff's reservation settlement level, and so do not affect the restricted entry equilibrium. (If filing costs were to rise so high as to deter genuinely injured plaintiffs from bringing suit, of course, they would preclude frivolous suits as well).

When the prior probability $p_{0}$ is less than the threshold $p_{1}^{*}$, the equilibrium is of a different type. The posterior probability $p_{1}$ must exactly equal the threshold $p_{1}^{*}$, and the defendant's probability of settlement must exactly equal $\sigma^{*}$.

PROPOSITION 3. If the prior probability of injury is below a threshold level, there is a unique equilibrium such that:

(a) All genuinely injured plaintiffs bring suit;

(b) Some but not all uninjured persons bring suit;

(c) Some strike suitors receive positive settlements while others drop their suits, and some injured plaintiffs fail to receive any settlement and consequently go to trial.

Proof: An equilibrium is determined by values of $\sigma$ and $p_{1}$ that are best responses to each other. Let $p_{0}<p_{1}^{*}$, and suppose $\sigma>\sigma^{*}$. Then a frivolous plaintiff's return from suit is strictly positive, so his best response is $q=1$ and $p_{1}=p_{0}$. But then defendant's best response is $\sigma=0$, which contradicts the supposition. Conversely, suppose $\sigma<\sigma^{*}$. Then a frivolous plaintiff's return from suit is strictly negative, so his best response is $q=0$ and $p_{1}=1$. But then defendant's best response is $\sigma=1$, again a contradiction. A similar argument shows that $p_{1} \neq p_{1}^{* *}$ cannot be an equilibrium. And, since defendant is indifferent about offering settlement when $p_{1}=p_{1}^{*}$ and a frivolous plaintiff is indifferent about suit when $\sigma=\sigma^{*}$, each strategy is a best response to the other. $\|$

In addition to being unique, the equilibrium is stable under an appropriately constructed dynamic adjustment process. If too many frivolous plaintiffs bring suit, the defendant will refuse to offer settlement, leading frivolous plaintiffs to exit until the defendant is again willing to settle with positive probability. If too few frivolous plaintiffs hring suit, the defendant will always offer settlement, leading frivolous plaintiffs to enter until the defendant is again willing to let some cases go to trial.

In this second type of equilibrium, competition among strike suitors drives the profits from bringing a strike suit to zero. Accordingly, I refer to this outcome as a competitive equilibrium. In many situations it will be the more plausible outcome. 
The entries of Table 1 can also be interpreted as the equilibrium proportion of valid claims when there is free entry to bringing suit. For instance, if the total costs of litigation are one-third of the amount at stake, and if a valid claim has a $75 \%$ chance of winning, then approximately $36 \%$ of all suits will be frivolous. If total costs of litigation are one-half the amount at stake and a valid claim has a $75 \%$ chance of winning, half of all suits will be frivolous. ${ }^{13}$

If the prior probability $p_{0}$ is exactly equal to the threshold $p_{1}^{*}$, a continuum of knife-edge equilibria exist, with $\sigma$ taking values in the interval $\left[\sigma^{*}, 1\right]$. In all such equilibria, all potential strike suitors bring suit, for if they did not, the defendant would strictly prefer to offer settlement and suit would be profitable. If $\sigma$ were less than the threshold $\sigma^{*}$, only the injured plaintiffs would sue, leading the defendant strictly to prefer $\sigma=1$. In all equilibria with settlement probability above $\sigma^{*}$, strike suitors earn positive profits; they earn zero profits in the equilibrium with $\sigma=\sigma^{*}$.

\section{Comparative statics}

The comparative statics of the restricted entry equilibrium are uninteresting. As observed above, all cases settle, and the proportion of valid claims is just the exogenous value $1-p_{0}$. None of the other exogenous variables affect either the probability of settlement or of suit, although they do affect the settlement amount. The competitive equilibrium, in contrast, depends upon all the exogenous variables. Consider first the equilibrium values of two endogenous variables: $p_{1}$, the proportion of claims that are valid, and $\sigma$, the proportion of suits that settle.

PROPOSITION 4. In competitive equilibrium, the proportion of lawsuits that are frivolous:

(a) is invariant to the prior probability of injury;

(b) increases with the trial costs of the defendant;

(c) increases with the trial costs of a genuinely injured plaintiff;

(d) decreases as the amount of the expected judgment increases;

(e) is invariant to the cost of filing a lawsuit.

Proof: By differentiation of Equation 2 with respect to $p_{0}, k, t, w A$, and $c$. $\|$

Proposition 5. In competitive equilibrium, the proportion of lawsuits that settle:

(a) is invariant to the prior probability that an injury occurred;

(b) is invariant to the trial costs of the defendant;

(c) increases with the trial costs of a genuinely injured plaintiff;

(d) decreases as the amount of the expected judgment increases;

(e) increases with the cost of filing a lawsuit.

ProOF: By differentiation of Equation 4 with respect to $p_{0}, k, t, w A$, and $c$. $\|$

Note that although the equilibrium values of $\sigma$ and $p_{1}$ are simultaneously determined in equilibrium, the equations defining them, 2 and 4 , are independent.

${ }^{13}$ For readers who distrust mixed strategy equilibria, it may be first observed that since the equilibrium is unique, no other strategy, pure or mixed, can persist. Second, the equilibrium is also stable. Third, one can postulate a slightly more complex model in which individual defendants differ in their trial cost $k$ and individual plaintiffs differ in their entry cost $c$. This would imply a unique pure strategy equilibrium. As Harsanyi (1973) has demonstrated, the equilibrium of such a variable-cost model approaches in the limit the mixed-strategy equilibrium of the simple model as the range of costs is shrunk to a single point. 
Hence it is possible to perform comparative statics by working with a single equation.

Proposition 4 states that in competitive equilibrium the same fraction of suits will be frivolous no matter how implausible or unlikely the plaintiff's claim is $e x$ ante. The underlying intuition is that it is just this fraction that makes a defendant indifferent between settling and going to trial, and in equilibrium the defendant must be indifferent between the two. (If the prior probability is sufficiently large, of course, the equilibrium will be of the restricted entry type.)

Similarly, the filing cost does not affect the number or proportion of frivolous suits, since it does not affect the defendant's willingness to settle either directly or indirectly. While changes in filing cost do have effects in equilibrium, such effects are entirely concentrated on the frequency of settlement. This result is perhaps surprising; it implies that policies that aim to discourage strike suits by increasing the costs of filing will not work, so long as the filing cost is still below a valid claim's settlement value. Kaising $c$ above $w A-t$ will discourage frivolous claims, but at the cost of discouraging valid ones as well.

The reason why higher defendant's trial costs increase the relative proportion of strike suits is that higher defense costs make trial less attractive for the defendant and increase his willingness to settle; accordingly, more strike suitors enter. Similarly, an increase in the plaintiff's trial costs $t$ also increases the equilibrium proportion of strike suits. This is because higher costs reduce the amount needed to induce an injured plaintiff to settle. The defendant will therefore be more willing to settle and will tolerate a higher proportion of frivolous suits in order to do so. (Indeed, by a similar argument one may see that any policy that reduces a genuinely injured plaintiff's return from trial will increase the proportion of strike suits.)

Accordingly, the popular wisdom that strike suits are an especially severe problem in the fields of antitrust and medical malpractice may be explained by the complexity and high costs of both trying and defending such claims. Similar reasons may also explain assertions that strike suits are common in the areas of securities law and products liability, and in the class action setting as well.

Finally, an increase in the expected judgment amount, $w A$, will reduce the proportion of frivolous lawsuits. This is because an increase in the stakes raises the amount necessary to settle the case and reduces the relative importance of trial costs. The defendant will be more willing to risk the costs of trial and will tolerate fewer frivolous suits in equilibrium. ${ }^{14}$

If this result seems counterintuitive, consider an example of two claims that might be alleged against a grocery store: a spinal injury from a slip and fall, and an overcharge on a can of soup. A customer claiming to have been overcharged is more likely to be indulged, because contesting the claim is too expensive to be worthwhile. The grocery is more likely to contest the slip and fall case, in contrast, since the amount of damages justifies the defense. One should therefore expect the equilibrium proportion of frivolous overcharge claims to be higher.

This result has at least one notable policy implication: detrebling antitrust damages should increase the proportion of frivolous suits brought, contrary to common

\footnotetext{
${ }^{14}$ Of course, individual parties may find it worthwhile to increase their trial expenditures $t$ and $k$ in cases with higher stakes. Whether the total effect is an increase or reduction in frivolous suits depends on the elasticity of trial costs with respect to the expected stakes. If, for instance, expenditure is proportional to the stakes, a change in the expected judgment will have no effect on the equilibrium proportion of frivolous suits. Most empirical evidence suggests, however, that trial expenditure is inelastic with respect to the stakes, implying that higher stakes will on balance reduce the proportion of strike suits.
} 
assertions. This implication, however, depends on the assumption that genuinely injured plaintiffs are still willing to bring suit for actual damages. Some number of antitrust claims are sufficiently complicated and uncertain that their expected recovery value would fall below their trial costs if damages are detrebled. Antitrust defendants and their political advocates may wish to label such claims as frivolous; under such a definition detrebling damages would indeed eliminate such suits, as well as the purely meritless suits that accompany them in equilibrium. Whether or not such marginal claims should be brought, of course, depends as a matter of social policy on their relative costs and benefits in terms of encouraging efficient market conduct. I would prefer to reserve the label "strike suit" for those suits that are purely without merit as a matter of positive law. Whether it is desirable on efficiency grounds to change the substantive law of antitrust to eliminate genuine claims is a separate issue.

As for Proposition 5, its underlying intuition is that the equilibrium settlement probability must leave a frivolous plaintiff indifferent whether to bring suit. A marginal increase in filing costs will make suit less attractive, requiring a corresponding increase in the probability of settlement. Note that if bringing suit is costless, entry by strike suitors eliminates settlement entirely, forcing all genuinely injured plaintiffs to trial. An increase in the expected award makes suit more attractive and hence decreases the equilibrium settlement frequency. An increase in the plaintiff's trial cost will also make suit less attractive by reducing the settlement amount, $w A-t$. Therefore it also requires an increase in the equilibrium settlement frequency.

\section{Analysis of social welfare}

For purposes of evaluating social welfare, the number of valid claims or the probability of settlement are not of ultimate concern. More important are the total costs of litigation and the net payments made and received by the various parties. Net payments by defendants reflect the extent to which the liability system can deter inefficient behavior and encourage optimal precaution. ${ }^{15}$ Payments received by genuine plaintiffs reflect the system's ability to achieve compensation for injury. Both types of payments are also important for purposes of distributional equity generally, and total litigation costs measure the legal system's administrative efficiency.

Let us take the prior probability of injury as given, and first consider the distributional effects of litigation. The number of lawsuits filed, denoted as $N_{s}$, equals $p_{0}+\left(1-p_{0}\right) q$. Equation 3 implies:

$$
N_{s}=\frac{p_{0}}{p_{1}}=p_{0}\left(\frac{w A+k}{w A-t}\right)
$$

The total number of cases going to trial is $N_{t}=p(1-\sigma)$, or substituting into Equation 4:

$$
N_{t}-p_{0}\left(\frac{w A-t-c}{w A-t}\right)
$$

With perfect competition in filing suit, frivolous plaintiffs earn zero expected profits in equilibrium. Since the defendant chooses the settlement amount to leave

${ }^{15}$ On this issue, see Polinsky and Rubinfeld (1988). 
an injured plaintiff indifferent between settlement and trial, the net expected gains to injured plaintiffs equals $p_{0}(w A-t-c)$. Net expected loss to the defendant is just $N_{s} \sigma(w A-t)+p_{0}(1-\sigma)(w A+k)=p_{0}(w A+k)$.

Denote as $L$ the total expected litigation costs. Since the cost of each suit is $c$ and the cost of each trial is $(t+k)$, expected litigation expenditures are:

$$
L=p_{0} c\left(\frac{w A+k}{w A-t}\right)+p_{0}(t+k)\left(\frac{w A-t-c}{w A-t}\right)=p_{0}(c+t+k)
$$

Equation 8 has an interesting interpretation. Total expenditure on litigation in competitive equilibrium exactly equals the amount that would be expended if only valid claims were brought and if all suits went to trial. Indeed, since there is no incentive to bring a frivolous claim absent settlement, a ban on settlement would have absolutely no effect on the total costs of litigation. Rent-seeking by strikc suitors completely exhausts the surplus from settlement bargaining. ${ }^{16}$

PROPOSITION 6. In competitive equilibrium, the expected social cost of litigation would be unaffected by a ban on settlement. The expected social cost of litigation would be increased by an increase in either filing costs or trial costs.

ProOF: By inspection of Equation 8. \|

Proposition 6 implies it would not be desirable to attempt to discourage frivolous suits by raising real filing costs, even though doing so would increase the proportion of cases that settle. The extra costs incurred per suit would more than outweigh the decrease in trial costs incurred. Moreover, the entire cost increase would be concentrated on injured plaintiffs, undercutting the goal of compensation. Increasing the plaintiff's real trial costs would similarly increase expected litigation costs while undercutting compensation. An increase in defendant's real trial costs would also increase total costs but would at least raise the deterrent value of litigation.

\section{APPLICATIONS TO POLICY ISSUES IN CIVIL PROCEDURE}

In this section, I apply the competitive equilibrium analysis to a number of policy changes in civil procedure that have been proposed to deal with the strike suit phonomenon.

\section{Stricter proof and pleading requirements}

Some critics of current procedure have proposed stricter pleading and proof requirements, or other rules that would require plaintiffs to engage in a higher degree of preparation before filing suit. The ostensible goal of such proposals is to raise the cost of bringing frivolous claims relative to valid ones and hence to improve the average merit of cases brought. Since such requirements would reduce the amount of preparation needed at trial, it is argued, they would not nccessarily change the total cost of litigation for genuine plaintiffs.

${ }^{16}$ This result depends upon the assumption that all plaintiffs face the same initial cost in bringing suit; i.e., that rent-seeking is perfectly competitive. If potential plaintiffs differed in their values of $c$, those with lower $c$ would earn positive rents in equilibrium, and not all the gains from bargaining would be dissipated. 
I model such proposals as increasing the fraction of total litigation costs incurred when filing, that is, as raising $c$ and lowering $t$ by an equivalent amount. Since increasing $c$ has no effect on the frequency of strike suits, while decreasing $t$ decreases their frequency, the net result is a reduction in strike suits.

To see the effect on the probability of settlement, let the variable $z$ denote the cost that is shifted forward by the stricter procedures. Filing costs would then become $c+z$ while plaintiff's trial cost would become $t-z$. Substituting into Equation 4:

$$
\sigma^{*}=\frac{c+z}{w A-t+z}
$$

Differentiating 9, one finds that settlement becomes more frequent as costs are shifted toward the beginning of the lawsuit.

Nonetheless, Equation 8 shows that a stricter pleading rule would have no effect on total expected costs. While it would reduce both the number of strike suits and the number of trials, it would increase costs in all suits that settle before trial, and the three effects precisely balance. Furthermore, the welfare of each type of litigant would be unchanged, so there would be no effect on either compensation or deterrence.

\section{English rule of litigation finance}

Some commentators have recommended that the U.S. adopt the English practice for allocating costs, under which the losing party must indemnify the winner for his cost of litigation. Under the prevailing American rule, in contrast, each party bears his own costs regardless of the outcome of trial. Proponents of the English rule have conjectured that its adoption would reduce both the general level of legal expenditure and the number of strike suits in particular. I have elsewhere attempted to cast doubt on the former claim (Katz, 1987), and the model presented here implies little support for the latter claim as well.

Under the English rule, a prevailing plaintiff not only recovers the stakes $A$ but is also reimbursed for his costs in the amount $(t+c)$. Should an injured plaintiff lose at trial, conversely, he must pay the defense cost $k$. The expected gain from trial for an injured plaintiff, once filing costs are sunk, equals:

$$
G_{t}=w A-t+w(c+t)-(1-w) k
$$

This differs by an amount $u \equiv w(c+t)-(1-w) k$ from the value of a valid claim under the American rule. The English rule increases the required settlement if and only if this amount is positive, which it is whenever the probability of liability $w$ is greater than $k /(c+t+k)$. Let us assume that the adoption of the English rule will not change the genuine plaintiff's decision to sue. As Shavell's (1982) well-known article has shown, the English rule can deter some genuine claims that the American rule would encourage. On the other hand, if the defendant's costs are small relative to the plaintiff's, or if total costs are large relative to the stakes, the English rule can encourage some genuine claims that the American rule would deter. ${ }^{17}$ Since Shavell has analyzed these effects thoroughly,

${ }^{17}$ To illustrate, suppose that the total costs of litigation are approximately equal for the two parties $(c+t=k)$. Then the English rule improves the position of genuine plaintiffs with a greater than $50 \%$ chance of winning at trial, and worsens the position of genuine plaintiffs with less than a $50 \%$ chance of winning at trial. 
however, I abstract from them here, and instead focus on how an indemnification rule affects frivolous claims aside from any effect it has on genuine claims. It should be apparent that any change in the number of genuine claims brought, whether or not it results from the English rule, will affect in proportion the number of associated strike suits.

I consider a more general class of cost shifting rules by introducing a parameter $b \in[0,1]$, which represents the fraction of costs that a winning party is entitled to recover from the loser. Under the American rule, $b=0$; under the English rule $b=1$. An injured plaintiff can expect to gain $w A-t+b u$ at trial, and a defendant would expect to pay $w A+k+b u$ at trial if the claim is valid. By reasoning analogous to the previous section, the equilibrium proportion of valid claims is:

$$
p_{1}^{*}=\frac{w A-t+b u}{w A+k+b u}
$$

The equilibrium probability of settlement would be:

$$
\sigma^{*}=\frac{c}{w A-t+b u}
$$

Accordingly, moving in the direction of the English rule would decrease the proportion of frivolous suits if and only if $u>0$, that is, if the English rule would improve the position of a genuinely injured plaintiff. Similarly, moving in the direction of the English rule would decrease the equilibrium probability of settlement if and only if it improved the position of an injured plaintiff.

Furthermore, strike suitors dissipate all the social gains from settlement under any cost allocation rule. Since the number of suits is $N_{s}=p_{0} / p_{1}^{*}$, and the number of trials is $N_{t}=p_{0}\left(1-\sigma^{*}\right)$, total expccted litigation costs equal:

$$
\begin{aligned}
L & =p_{0} c\left(\frac{w A+k+b u}{w A-t+b u}\right)+p_{0}(t+k)\left(\frac{w A-t+b u-c}{w A-t+b u}\right) \\
& =p_{0}(c+t+k)
\end{aligned}
$$

and are unaffected by the choice of the financing rule. The English rule's effects on the number of suits and on the number of trials exactly cancel out.

The financing rule does, however, affect the welfare of the individual parties. If $u>0$, a shift to the English rule will benefit injured plaintiffs and hurt defendants, just as it would in the absence of frivolous suits. In summary:

PROPOSITION 7. In free entry equilibrium, a shift toward the English rule of litigation finance will:

(a) decrease the frequency of frivolous suits if and only if an injured plaintiff would benefit from the English rule;

(b) increase the frequency of trials if and only if an injured plaintiff would benefit from the English rule;

(c) leave unchanged the total social costs of litigation.

Proof: (a) and (b): By differentiation of Equations 11 and 12 with respect to $b$. (c) By comparison of Equations 8 and 13. $\|$

Contrary to its proponents' claims, the English rule provides no remedy to the problem of strike suits. The reason is that since strike suitors always drop out 
before a trial, they never have to pay any defense costs. Indeed, since strike suitors never go to trial, there are no defense costs incurred in their cases. The cost of strike suits, rather, is that they create an externality by interfering with the settlement of other genuine claims. A simple indemnification remedy does not remove the externality.

\section{Refundable deposits or penalties}

In order to deter frivolous claims, one needs to exact a penalty not just when a claim is disproven at trial, but also when a claim is dropped. The simplest way to do this would be to require all plaintiffs to deposit an amount $D$ when filing suit. The deposit could be refunded if the validity of the plaintiff's claim is established at trial, or if the defendant agrees to the refund when settling. Otherwise, the deposit would be forfeited to the court. ${ }^{18}$ Suppose further that even if a genuine plaintiff is not assured of winning at trial, the court can determine that his claim is not frivolous and will return his deposit.

Once filing costs are sunk, a genuine plaintiff stands to gain either $w A-t+$ $D$ from going to trial or $S+D$ from accepting settlement, so his reservation price is still $w A-t$. (The defendant will always agree to the return of the deposit, since by doing so he can offer a lower settlement.) The deposit changes the reservation price of the strike suitor, however, who now will pay the defendant up to the amount of the deposit in order to settle.

Specifically, both plaintiff types will accept an offer of $w A-t$. An offer of $-D$ will be accepted only by a strike suitor, and will cost the defendant $p_{0}(w A+k+$ $D)-D$. The defendant will be indifferent between high and low offers when $p_{0}$ equals:

$$
p_{1}^{*}=\frac{w A-t+D}{w A+k+D}
$$

and by the same argument as the previous section, this is the competitive equilibrium proportion of valid claims. Hence a higher deposit reduces the proportion of strike suits, because a strike suitor always loses his deposit-either to the court if he drops the case, or to the defendant if he settles.

The equilibrium settlement probability equals:

$$
\sigma^{*}=\frac{c+D}{w A-t+D}
$$

because, as above, this is the value that makes an uninjured plaintiff indifferent whether to sue. Since a higher deposit makes strike suits less attractive, it increases the settlement probability sustainable in equilibrium.

\footnotetext{
${ }^{18}$ It should be apparent that an actual deposit is not necessary, so long as the court can fine the plaintiff an amount equal to $D$ if he either drops the case without settling or if his claim is shown in court to be frivolous. The administrative costs of collecting such a fine would likely be minimized, however, if it were structured as a refundable deposit. A scheme which paid the deposit to the defendant upon forfeit would operate similarly.
} 
It follows that total expected litigation costs equal:

$$
\begin{aligned}
L & =p_{0} c\left(\frac{w A+k+D}{w A-t+D}\right)+p_{0}(t+k)\left(\frac{w A-t-c}{w A-t+D}\right) \\
& =p_{0}\left(c+(t+k) \frac{w A-t}{w A-t+D}\right)
\end{aligned}
$$

which is decreased by a higher deposit. As $D$ approaches infinity, $\sigma$ and $p_{1}$ approach 1; a sufficiently large deposit comes arbitrarily close to the first-best outcome, in which only injured plaintiffs bring suit and all valid claims are settled. In order to deter absolutely all strike suits, however, an infinitely high deposit would be required.

The problem with such a scheme is that in reality courts cannot perfectly determine whether a losing claim was frivolous or not, so that there is some risk that a genuine plaintiff will be penalized. A penalty or deposit high enough to deter most strike suits would deter many if not most valid claims as well. Furthermore, even if the risk is negligible that a losing valid claim will be judged frivolous, liquidity constraints may prevent genuine plaintiffs from bringing suit. Accordingly, such penalties may be of limited utility in deterring strike suits.

\section{A MODEL WITH A CONTINUUM OF PLAINTIFF TYPES}

This section briefly presents a variation on the basic model in which the amount of injury suffered by a genuine plaintiff can vary continuously. Accordingly, the defendant can choose to settle with only a subset of injured plaintiffs. It turns out that this formulation allows equilibria in pure strategies; nonetheless, most of the results of the basic model carry over in spirit.

As before, suppose that a compensable injury in the amount of $A$ has occurred with prior probability $p_{0}$. The filing cost and the plaintiff's and defendant's trial costs are again denoted as $c, t$ and $k$ respectively. As before, $w$ denotes the probability that an injured plaintiff will win at trial. Let us now refer to a plaintiff's probability of winning at trial as his type, and let the type $w$ be distributed along the unit interval with probability density $f(w)$ and cumulative density $F(w)$, with both density functions conditional on injury having occurred. ${ }^{19}$

The injured plaintiffs fall into two groups. Those with type $w \geq \frac{c+t}{A}$ are substantially injured, and will bring suit and go to trial even if no settlement is offered. Those with type $w<\frac{c+t}{A}$ are only mildly injured and would not bring suit unless they expected some settlement to be offered. ${ }^{20}$ Whether this second group should be classed with strike suitors as a normative matter is debatable. In some sense

\footnotetext{
${ }^{19}$ As before, readers may prefer to interpret $w$ as representing the extent of injury rather than the likelihood of recovery. This will not affect the results so long as the parties are risk-neutral.

${ }^{20}$ The mildly injured group can be further divided into two subsets. Those plaintiffs with type between $t / A$ and $\frac{c+t}{A}$ would not sue unless they expected a settlement offer. Once they have sunk the costs of suit, however, they can credibly threaten to continue on to trial, and the defendant must take this into account when choosing a settlement offer. Those plaintiffs with type below $t / A$, in contrast, would never want to go to trial. From the defendant's standpoint they are identical to strike suitors.
} 
they may deserve compensation, since only the costs of trial interfere with their obtaining their entitlements. On the other hand, their injuries are mild enough that they would not go to trial, and they can obtain a settlement only by free riding on the more severely injured plaintiffs in the population. In the discussion, I will group them with the pure strike suitors, and refer only to the high-injury group as having genuine claims.

Let $q$ again denote the probability that a purely frivolous plaintiff brings suit, and additionally, let $q(w)$ denote the probability that a plaintiff of type $w$ brings suit. The sequential equilibrium is found by backwards induction from the last stage of the game. At this point, a plaintiff with type below $t / A$ will accept any positive settlement offer and will drop the case if no settlement is offered. Any plaintiffs with type $w \geq t / A$, in contrast, expect a non-negative return from trial once filing costs are sunk. Accordingly, they will only accept a settlement offer at least as large as $w A-t$, and will reject any lower offer in favor of trial.

The defendant, therefore, anticipates that a non-negative settlement offer in the amount of $S$ will be accepted by all plaintiffs with type less than or equal to $\frac{S+t}{A}$. Offering $S$ therefore has an expected payout of:

$$
L(S)=S\left[q\left(1-p_{0}\right)+p_{0} \int_{0}^{\frac{S+t}{A}} q(w) d F(w)\right]+p_{0} \int_{\frac{S+t}{A}}^{1} q(w)(w A+k) d F(w)
$$

where the first term reflects the cost of accepted offers, and the second term reflects the cost of trial following rejected offers. The defendant chooses $S$ to minimize expected payout; differentiating 17 , we get the Kuhn-Tucker first-order condition:

$$
S(S+t-A) L^{\prime}(S)=0
$$

where:

$$
L^{\prime}(S)=\left[q\left(1-p_{0}\right)+p_{0} \int^{\frac{S+t}{A}} q(w) d F(w)\right]-p_{0} \frac{t+k}{A} q\left(\frac{S+t}{A}\right) f\left(\frac{S+t}{A}\right)
$$

and the boundary conditions are $0 \leq S \leq A-t$. Denote the settlement amount that satisfies 18 as $S^{*}$. I assume that the second-order condition for a minimum is satisfied:

$$
\begin{aligned}
L^{\prime \prime}(S)=\frac{p_{0}}{A}\left[q\left(\frac{S+t}{A}\right) f\left(\frac{S+t}{A}\right)-\frac{t+k}{A}(\right. & \left(\frac{S+t}{A}\right) f^{\prime}\left(\frac{S+t}{A}\right) \\
& \left.\left.+q^{\prime}\left(\frac{S+t}{A}\right) f\left(\frac{S+t}{A}\right)\right)\right]>0
\end{aligned}
$$

implying that $S^{*}$ minimizes the defendant's payout. 


\section{Equilibrium of the continuous model}

As in the two-type model, the nature of the equilibrium depends upon whether the prior probability of injury exceeds a threshold equal to:

$$
p^{*}=\frac{1}{1-F\left(\frac{c+t}{A}\right)+\frac{t+k}{A} f\left(\frac{c+t}{A}\right)}
$$

PROPOSITION 8. If the prior probability of injury is above a threshold level, then in the unique equilibrium all potential plaintiffs bring suit, and the defendant offers a settlement strictly greater than the plaintiff's fling cost.

Proof: Let $p_{0}>p^{*}$, and suppose all plaintiff types bring suit. Then from 19 and the fact that $q\left(\frac{c+t}{A}\right)=1$ it follows that:

$$
L^{\prime}(c)=1-p_{0}\left[1-F\left(\frac{c+t}{A}\right)+\frac{t+k}{A} f\left(\frac{c+t}{A}\right)\right]=1-\frac{p_{0}}{p^{*}}<0
$$

Furthermore, it follows from the second-order condition 20 that $L^{\prime}(S) \leq L^{\prime}(c)<$ 0 for any settlement offer $S \leq c$. Thus the defendant's optimal offer $S^{*}$ is greater than $c$, even when all plaintiff types bring suit. It follows $a$ fortiori that $S>c$ when some frivolous plaintiffs do not sue. But then suit yields positive profits, so all plaintiffs will indeed sue. By continuity, there exists some $S \in[c, A-t]$ that satisfies 18 when $q(\cdot)=1$. The second-order condition ensures that this is a unique solution to 18 . $\|$

COROLlARY 1. The likelihood of an equilibrium in which the defendant offers a settlement strictly greater than the filing cost:

(a) increases with the prior probability of injury;

(b) increases with the costs of a defense;

(c) falls as the filing cost rises;

(d) is ambiguously affected both by the plaintiff's trial costs and by the size of the injury.

PROOF: Clearly, the higher is $p_{0}$ the more likely it is to exceed the threshold level $p^{*}$. Differentiation of 21 shows that $\partial p^{*} / \partial k<0$, that $\partial p^{*} / \partial c>0$ (from the secondorder condition), and that the signs of $\partial p^{*} / \partial t$ and $\partial p^{*} / \partial A$ are ambiguous. \|

COROLlARY 2. Assuming an interior solution, the settlement amount offered in restricted entry equilibrium:

(a) increases with the prior probability of injury;

(b) increases with the costs of a defense;

(c) is ambiguously affected both by the plaintiff's trial costs and by the amount of the potential judgment.

PROOF: An interior solution means the settlement amount is implicitly defined by the first-order-condition 19. Differentiating 19 with respect to $S, p_{0}, k, t$, and $A$, and applying the second-order-condition 20 , we find that $\partial S^{*} / \partial p_{0}>0, \partial S^{*} / \partial k>$ 0 , and that $\partial S^{*} / \partial t$ and $\partial S^{*} / \partial A$ have ambiguous signs. $\|$ 
The underlying intuition of the proposition is that when the prior probability of injury is sufficiently high, the defendant prefers an offer strictly greater than the filing cost no matter what the uninjured plaintiffs do. This ensures that strike suits earn positive profits, so all plaintiffs bring suit. In contrast to the two-type model, however, not all cases need settle before trial.

Proposition 8 and its corollaries correspond to Propositions 1 and 2 in Bebchuk (1988). The outcome is a restricted entry equilibrium, since there are not enough potential strike suitors to drive the profits from bringing a strike suit to the competitive level. The corollaries confirm Bebchuk's findings that the likelihood of such an equilibrium, as well as the actual settlement amount, rise with the prior probability of injury and the defendant's trial costs. His claims that the likelihood of such an equilibrium and the settlement amount rise with the plaintiff's trial costs, however, are not confirmed. Specifically, an increase in the plaintiff's trial costs results in two offsetting effects in restricted entry equilibrium. First, it increases the gain from settlement in any given case, making settlement (or a slight increase in the settlement offer) more attractive to the defendant; and second, it decreases the number of plaintiffs who would actually be willing to go to trial, making settlement (or a slight increase in the settlement offer) less attractive to the defendant. Bebchuk does not consider the second effect; when it is properly taken into account, the consequences of an increase in the plaintiff's trial costs become ambiguous. ${ }^{21}$

When the prior probability of injury is below the threshold $p^{*}$, conversely, the restricted entry equilibrium does not obtain. Instead, there is a generically unique set of competitive equilibria in which free entry by strike suitors drives the equilibrium settlement offer down to an amount just sufficient to cover the cost of filing suit.

PROPOSITION 9. If the prior probability of injury is below a threshold level, then in equilibrium:

(a) All genuinely injured plaintiffs bring suit;

(b) Some but not all potential strike suitors bring suit;

(c) All frivolous plaintiffs settle for an amount equal to their filing costs, and all plaintiffs with valid claims go to trial.

ProOF: An cquilibrium is determined by values of $S$ and $q(\cdot)$ that are best responses to each other. Let $p_{0}<p^{*}$, and first suppose that $S>c$. Then all plaintiffs' returns from suit are strictly positive, so $q(w)=1$ for all $w$. But then $L^{\prime}(S)>L^{\prime}(c)=$ $1-p_{0} / p^{*}>0$, so the defendant wants to choose $S<c$, which contradicts the supposition. Conversely, suppose $S<c$. Then a frivolous plaintiff's return from suit is strictly negative, so $q(w)=0$ for all $w<\frac{c+t}{A}$. But then $L^{\prime}(S)=0$ for all $S<c$, and $L^{\prime}(c)<0$, so that the defendant wants to choose $S>c$, again a contradiction. A similar argument shows that neither $q(w)=0$ nor $q(w)=1$ for all $w$ can be an equilibrium. By continuity, there exist values of $q(\cdot) \gg 0$ and $\ll$ 1 (not necessarily unique) such that $L^{\prime}(c)=0$. Since frivolous plaintiffs are

${ }^{21}$ The discrepancy between my results and Bebchuk's seems to originate in a difference of notation. In my framework, the plaintiff's type corresponds to the gross return expected at trial; in Bebchuk's framework the plaintiff's type corresponds to the net return after trial costs are subtracted. Bebchuk's notation is more compact, but has the disadvantage that a change in the trial costs should cause a shift in his entire probability distribution of types. Apparently, he overlooks this shift in the distribution when taking the derivatives to his Equations 7 and 9-the counterparts to my Equations 19 and 21. 
indifferent whether to sue when $S=c$, such values of $q(\cdot)$ are a best response to an offer of $c$, so this is an equilibrium. Any genuine plaintiff will bring suit, reject the offer of $c$, and go to trial. $\|$

While the competitive equilibrium is not unique with respect to the identity of the strike suitors, the equilibrium number and proportion of strike suitors are uniquely determined. From the first-order-condition 19, the equilibrium number of strike suitors is $\left[q\left(1-p_{0}\right)+p_{0} \int_{0}^{\frac{c+t}{A}} q(w) d F(w)\right]=p_{0} \frac{t+k}{A} f\left(\frac{c+t}{A}\right)$. The number of seriously injured plaintiffs, recall, was $p_{0}\left(1-F\left(\frac{c+t}{A}\right)\right)$. Hence the equilibrium proportion of genuine claims is:

$$
p^{*}=\frac{1-F\left(\frac{c+t}{A}\right)}{1-F\left(\frac{c+t}{A}\right)+\frac{t+k}{A} f\left(\frac{c+t}{A}\right)}
$$

\section{Comparative statics}

In competitive equilibrium, rent-seeking drives the settlement amount down to the filing cost. Changes in the other exogenous variables have no effect on equilibrium $S^{*}$, but do affect the equilibrium proportion of frivolous suits:

PROPOSITION 10. In competitive equilibrium, the proportion of frivolous lawsuits:

(a) is invariant to the prior probability of injury;

(b) increases with the trial costs of the defendant;

(c) is ambiguously affected by the plaintiff's trial costs, the filing cost, and by the amount of the potential judgment.

Proof: By differentiation of Equation 23. ॥

The effect of the prior probability of injury and the defendant's trial costs on the proportion of frivolous suits is the same in the continuous model as in the two-type model presented in the text. The effects of the variables $c, t$, and $A$ that arise in the two-type model are also present with a continuum of types. In the continuous model, however, these last variables also change the threshold $\frac{c+t}{A}$ that determines whether a plaintiff of type $w$ is frivolous or genuine. The net effect on the proportion of frivolous suits is therefore ambiguous. ${ }^{22}$

\section{Analysis of social welfare}

The welfare consequences of competitive equilibrium in the continuous model are even more striking than those of the two-type model. Because all frivolous suits settle for their filing costs and all genuine suits go on to trial, all plaintiff types get the same level of welfare as they would were there no settlement at all. Defendants, however, are strictly worse off than if there were no settlement; they

${ }^{22}$ If one ignores the effect that arises from changing the threshold $\frac{c+t}{A}$, the comparative statics of the continuous model are identical to those described for the two-type model in the text. 
must pay the costs of going to trial against genuine plaintiffs, and, in addition, they must pay the filing costs of all frivolous plaintiffs. Accordingly, the net social costs of litigation would actually be decreased if settlement were forbidden. Rentseeking by strike suitors dissipates an amount in excess of the surplus from settlement bargaining.

\section{Example: uniform distribution}

To illustrate, suppose that the plaintiff's type $w$ is uniformly distributed along the unit interval following an injury, so that $f(w)=1$ and $F(w)=w$. It follows that the second-order-condition is satisfied. The threshold probability of injury necessary for a restricted entry equilibrium to obtain is then $p^{*}=\frac{A}{A+k-c}$. Whenever the filing cost is less than the defense cost, as seems likely, this threshold will be contained in $[0,1]$ and increasing in $A$, so that buying off all strike suitors is less attractive when the potential stakes are higher. In this case, $S=k+$ $A\left(1-\frac{1}{p_{0}}\right)$, so that higher plaintiff's trial cost has no effect on the settlement amount, and higher stakes actually lower the settlement amount in restricted entry equilibrium. When filing costs exceed defense costs, this threshold probability exceeds one, so the equilibrium must be a competitive one.

In competitive equilibrium, the equilibrium proportion of genuine suits is $p^{*}=\frac{A-c-t}{A-c+k}$. This proportion is increasing in the stakes $A$, and decreasing in all manner of costs. Accordingly, frivolous suits make up a smaller proportion of suits when the potential stakes are higher, and a larger proportion when litigation costs are higher.

As an arithmetic example, suppose that plaintiff's and defendant's trial costs $t$ and $k$ each amount to one-sixth of the potential stakes $A$, and that the filing costs $c$ are close to zero. Then there would be a restricted entry equilibrium if the prior probability of injury were greater than $6 / 7$, and a competitive equilibrium otherwise. In competitive equilibrium, $2 / 7$ of all claims would be frivolous. If each party's trial costs increased to one-fourth of the potential stakes, there would be a restricted entry equilibrium if the prior probability of injury were greater than $80 \%$, and in competitive equilibrium $40 \%$ of all claims would be frivolous.

\section{CONCLUSIONS}

This article analyzes the equilibrium suit and settlement strategies of parties to a lawsuit when there is a possibility that the suit is frivolous. Because the defendant does not know whether a given lawsuit is frivolous or genuine, he may choose a strategy that leads to the settlement of frivolous claims or the trial of genuine ones. It turns out that a situation in which it is common knowledge that the plaintiff may drop the suit looks very different from one in which the plaintiff's threat to go to trial is credible. Several conclusions follow from the analysis.

First, so long as there are no barriers to bringing suit, it will generally be the case that some proportion of suits are frivolous. The reason for this is that if there were no frivolous suits brought, defendants would find it in their interest to offer substantial amounts in settlement. Such high offers, however, encourage the bringing of strike suits. Moreover, the number of frivolous suits as a proportion of all suits is unaffected by the frequency of genuine claims in the population of potential plaintiffs.

Second, the proportion of frivolous suits is directly related to both sides' trial costs. The prospect of an expensive trial will make the defendant a softer bar- 
gainer, leading him to tolerate a higher proportion of frivolous suits in equilibrium. Similarly, the proportion of strike suits is inversely related to the size of the potential judgment, since the higher stakes reduces the relative importance of trial costs and makes the defendant a harder bargainer. This suggests, for instance, that proposals to reduce the number of frivolous suits by detrebling antitrust damages may be misplaced.

Third, frivolous suits lead to at least two sorts of social costs. The first is the real resource cost involved in filing such suits. The second is the cost of the trials required because the presence of strike suitors prevents some genuine claims from settling. If there is free entry to bringing a frivolous suit, the entire surplus from the settlement of genuine claims can be dissipated. In the basic model of section 3 , the increased costs arising from frivolous claims are equivalent to the costs that would be suffered if settlement were actually prohibited. When the merits of the claim can vary continuously, as in Section 4, banning settlement could actually reduce the costs of litigation.

Fourth, policies proposed to remedy the problem of frivolous lawsuits generally have undesirable effects on the disposition of genuine claims. For example, the English rule of litigation finance, which requires the losing party to indemnify the winner for the cost of litigation, may reduce the frequency of frivolous suits. It does so, however, only by interfering with the settlement of meritorious suits and reducing the amount received by injured plaintiffs. Moreover, its total litigation costs are on balance no less than under the American rule in which each party must pay his own costs. Similarly, requiring each plaintiff to put up a refundable deposit that is forfeited if the suit is dropped will reduce total litigation costs, but is likely to prevent some genuine liquidity-constrained plaintiffs from obtaining compensation.

Settlement negotiation in lawsuits is obviously a complicated process, and these results warrant further investigation. An interesting extension of this model would consider situations where the plaintiff rather than the defendant makes the settlement offer. This would complicate matters by allowing the defendant to draw inferences not just from the fact of suit but also from the amount requested. Another realistic extension would be to allow multiple settlement offers, both before and at various points during the course of litigation. Preliminary results from research in progress suggest that much of the spirit of the single-offer model carries over to the multiple-offer case.

The paper also abstracts from a number of interesting aspects of settlement bargaining that should provide fertile ground for further research. For example, the model omits any mention of civil discovery, the process whereby a party can compel his adversary to turn over private information regarding the merits of the case. The opportunity to engage in discovery, at a cost, further enriches the litigants' strategies. It would also be useful to incorporate in the analysis the contingent fee, whereby the plaintiff's attorney agrees to be compensated by a percentage of the verdict or settlement. While the contingent fee has been criticized for its supposed contribution to the increase in litigation, the truth may be more complicated. The fact that an attorney is willing to take a percentage of a case as his compensation may be a good signal that the case has merit; accordingly, contingent fees may help to channel meritorious cases toward settlement, while screening out some frivolous claims. ${ }^{23}$

\footnotetext{
${ }^{23}$ On the basis of this conjecture, Judge Richard Posner dissented from an opinion providing state-appointed counsel to an indigent prisoner who wished to bring a medical malpractice suit against the prison physician. Posner reasoned that had the suit been meritorious, it would have been accepted by a private attorney on a contingent fee basis. See Merritt v. Faulkner, 697 F. 2d 761 (7th Cir., 1983).
} 
In summary, the incentives for settlement and negotiation in actual lawsuits are complex, and my results and recommendations should be taken as tentative. On the other hand, recent critics of the American legal system have been quite willing to make their own recommendations for its reform on efficiency grounds. My results also suggest that one should be cautious in applying "common sense" prescriptions for the judicial process that are not carefully based on an explicit theoretical model. This paper is intended as a step toward that goal.

\section{REFERENCES}

Bebchuk, Lucian (1984) "Litigation and Settlement Under Imperfect Information," Rand Journal of Economics, 15, 404-15.

Bebchuk, Lucian (1988) "Suing Solely to Extract a Settlement Offer,' Journal of Legal Studies, 17, 437-50.

Cooter, Robert and Thomas Ulen (1988) Law and Economics. Glenview, Illinois: Scott, Foresman, and Co.

Harsanyi, John (1973) "Games with Randomly Disturbed Payoffs: A New Rationale for Mixed Strategy Equilibrium Points," International Journal of Game Theory, 2, 1-23.

Katz, Avery (1986) Essays in the Economics of Litigation. Harvard University: unpublished Ph.D. dissertation.

Katz, Avery (1987) "Measuring the Demand for Litigation: Is the English Rule Really Cheaper," Journal of Law, Economics, and Organization, 3, 143-76.

Kritzer, Herbert, Austin Sarat, David Trubek, Kristin Bumiller, and Elizabeth McNichol (1984) "Understanding the Costs of Litigation: The Case of the Hourly-Fee Lawyer," American Bar Foundation Research Journal, 3, 559-604.

Nalebuff, Barry (1987) "Credible Pre-Trial Negotiation," Rand Journal of Economics, 18, $198-210$.

Ordover, Janusz and Ariel Rubenstein (1983) "On Bargaining, Settling, and Litigating: A Problem in Multistage Games with Imperfect Information," Working Paper, New York University, C.V. Starr Center for Applied Economics.

P'ng, Ivan P. L. (1983) "Strategic Behavior in Suit, Settlement, and Trial," Bell Journal of Economics, 14, 539-50.

Polinsky, A. Mitchell and Daniel Rubinfeld (1988) "The Welfare Implications of Costly Litigation for the Level of Liability," Journal of Legal Studies, 17, 151-64.

Rosenberg, David and Steven Shavell (1985) "A Model in Which Suits Are Brought for Their Nuisance Value,"' International Review of Law and Economics, 5, 3-13.

Rowe, Thomas (1984) "Predicting the Effects of Attorney Fee Shifting," Law and Contemporary Problems, 47, 139-71.

Salant, Stephen (1984) "Litigation of Settlement Claims Questioned by Bayesian Defendants," California Institute of Technology, Social Science Working Paper \#516.

Shavell, Steven (1982) "Suit, Settlement and Trial: A Theoretical Analysis Under Alternative Methods for the Allocation of Legal Costs," Journal of Legal Studies, 11, 55-81.

Trubek, David, Austin Sarat, William Felstiner, Herbert Kritzer, and Joel Grossman (1983) Civil Litigation Research Project: Final Report. Madison: University of Wisconsin Law School. 